\title{
Acid suppression in duodenal ulcer: a meta-analysis to define optimal dosing with antisecretory drugs
}

\author{
D B JONES, C W HOWDEN, D W BURGET, G D KERR, AND R H HUNT
}

From the Division of Gastroenterology and Intestinal Disease Research Unit, McMaster University, Hamilton, Ontario, Canada, and Royal Shrewsbury Hospital, Shrewsbury

SUMmaRY Many different dosage schedules of antisecretory drugs for the treatment of duodenal ulcer are recommended. The relationship between degree of acid suppression and therapeutic efficacy has not been precisely defined for these drugs. We have examined the association between suppression of intragastric acidity and duodenal ulcer healing rates for a number of therapeutic regimens. For the $\mathrm{H}_{2}$ receptor antagonists alone, the most significant correlation with healing rates was with suppression of intragastric acidity at night $(r=0.926 ; p=0 \cdot 0001)$. When other classes of drug: high dose antacid, omeprazole and a synthetic prostaglandin (enprostil) were included in the analysis, the closest correlation was with suppression of total 24 hour intragastric acidity $(r=0 \cdot 911$; $\mathrm{p}<0.0001)$. Stepwise linear regression analysis was used to investigate the relative contributions to healing of suppression of acidity during the day and night. Suppression of nocturnal acidity was found to be the single most important factor in explaining healing rates. No further benefit was obtained with daytime suppression for $\mathrm{H}_{2}$ receptor antagonists; suppression of acidity at night accounted for $86.1 \%$ of the observed variation in healing rates among different regimens of $\mathrm{H}_{2}$ receptor antagonists. When all classes of drugs were analysed, inclusion of daytime suppression produced a significant improvement in correlation over nocturnal suppression alone. Drug regimens providing potent suppression of nocturnal acidity produce the highest healing rates in controlled clinical trials. The healing rate for any dose regimen of an antisecretory drug can be predicted from a knowledge of its effect on intragastric acidity. For the $\mathrm{H}_{2}$ receptor antagonists, suppression of nocturnal acidity is the most relevant in this context. Moderate suppression of acidity achieves ulcer healing rates at four to eight weeks which are comparable with those seen with potent suppression at two to four weeks. Increasing degrees of suppression merely accelerate healing.

Dosage schedules for antisecretory drugs in the treatment of duodenal ulcer have largely been based on pharmacokinetics. The plasma concentration of a drug which produces a $50 \%$ reduction in submaximally stimulated gastric acid secretion, is calculated (the $\mathrm{IC}_{50}$ ), and the drug administered in an attempt to maintain the plasma concentration above the $\mathrm{IC}_{50}$ for a substantial portion of the 24 hour period. The basic tenet of this thesis is that the pharmacokinetic

Address for correspondence: Professor Richard H Hunt. Division of Gastroenterology, Room 4W8. McMaster University Medical Centre, 12(x) Main Street West, Hamilton. Ontario LXN 37.5. Canada.

Received for publication 10 April 1987. behaviour of any drug correlates with its antisecretory effect. While this may be true for some drugs such as cimetidine, 'it is not so for ranitidine ${ }^{2}$ or omeprazole. ${ }^{3}$

Initial dosage regimens of $\mathrm{H}_{2}$ receptor antagonists were designed to suppress gastric acid secretion to as great a degree and for as much of the 24 hour period as possible. More recently, attention has focused on the simplification of dosage recommendations, and on the suppression of acidity at night. ${ }^{+}$There are a number of reasons for targetting the pharmacological effect to the night. Although patients with duodenal ulcer secrete more acid throughout the 24 hour 
period ${ }^{5}$ they often show high levels of acid secretion at night. ${ }^{--x}$ This represents a prolonged period of basal acid secretion which is unbuffered as no food is consumed. Experience with the $\mathrm{H}_{2}$ receptor antagonists shows that it is easier to inhibit basal secretion than stimulated secretion as occurs during the daytime period. ${ }^{9}$ Nocturnal maintenance treatment with $\mathrm{H}_{2}$ receptor antagonists is effective in preventing duodenal ulcer relapse. ${ }^{112}$ - Suppression of nocturnal acid secretion has been considered to be the single most important factor in duodenal ulcer healing." Patients who show a poor clinical response to conventional doses of $\mathrm{H}_{2}$ receptor antagonists show a reduced suppression of intragastric acidity at night. ${ }^{13}$ Taken together these observations suggested that $\mathrm{H}_{2}$ receptor antagonists given in full dose at night might be an effective primary treatment for duodenal ulcer. ${ }^{+}$

In selecting the optimal dose schedule of an antisecretory drug for duodenal ulcer, studies have usually been undertaken to examine the effect of the drug on 24 hour, and particularly on nocturnal intragastric acidity. This approach has now become widely accepted in the evaluation of any new antisecretory agent. The present study has attempted to appraise critically the effects of different dose schedules of available antisecretory agents on 24 hour and nocturnal intragastric acidity and nocturnal acid secretion in relation to duodenal ulcer healing to determine the optimal dose regimens from those studied to date.

\section{Methods}

\section{PATIENTS}

In order to explore the relationship between the suppression of gastric acid secretion and the healing of duodenal ulcer the principles of meta-analysis to correlation have been applied. ${ }^{15}$ This method permits the investigator to assess the significance of any relationship or trend from pooled data that might not be evident in any of the many smaller studies reported. Using this approach, we sought and reviewed all published studies of the clinical pharmacology of antisecretory drugs on 24 hour gastric secretion from the literature with a computer assisted Medline search. All those using aspiration techniques, and meeting the criteria described below, were included. ${ }^{+4 \mid(2) 31}$ In such studies, measurements of intragastric $\mathrm{pH}$ taken hourly over a 24 hour period allow hydrogen ion activity, or acidity, to be derived. In these studies, special attention has traditionally been paid to acid secretion during the night. As subjects do not eat over this time, the entire gastric secretion can be collected by continuous aspiration. Hourly volume and titratable acidity are measured and acid output is calculated as the product of these two factors.

In order to pool data certain rules have been established by Goldman and Feinstein ${ }^{32}$ and have been used in all studies cited here. All had been undertaken in duodenal ulcer patients, all of whom were in remission, not taking treatment except under the conditions of study, and all studies measured $\mathrm{pH}$ (which was then converted to $\mathrm{H}^{+}$activity), with the exception of one which measured titrateable acidity. The single criterion that was not met fully, involved the use of percentage reduction of acidity and nocturnal acid output because the raw data were not given in most papers. For the index of antisecretory effect of a drug we have therefore taken the percentage suppression of mean 24 hour or nocturnal intragastric acidity or nocturnal acid output with secretion on placebo given to represent $100 \%$. Because: (1) no studies reported either $100 \%$ or $0 \%$ reductions; (2) the range of secretion and suppression in these studies, was similar (normal subjects and ZollingerEllison patients were not included); and (3) these pharmacological studies all had similar, small sample sizes, reducing the possibility of weighting larger studies, a significant error from pooling percentages is not likely.

In addition to fulfilling the criteria of Goldman and Feinstein all studies were placebo controlled, and with the exception of four $1+162+25$ were done in a randomised manner, while 10 were either single or double blind. Most studies of 24 hour gastric acidity have not routinely reported reduction of intragastric acidity during the daytime period. Where both 24 hour and nocturnal data were available, we have derived a new variable which defines the degree of daytime suppression:

$$
\text { Acid suppression }(\text { day })=
$$

$(18 \times 24$ hour suppression $)-(8 \times$ nocturnal suppression $)$

10

This is derived as follows: during the 24 hour period, three meals are consumed. For the two hours after each meal, contamination of gastric secretion with food may result in spurious $\mathrm{pH}$ recordings. These six hours are therefore ignored. There are 18 hours remaining for which data are available. The value reported for suppression of 24 hour intragastric acidity is therefore given a weighting factor of 18 . The nocturnal period in most studies has covered eight hours, so the degree of suppression of nocturnal acidity is given a weighting of 8 . The difference between these two values is then divided by the remaining 10 hours to give the (apparent) mean reduction of daytime intragastric acidity.

For each dose schedule for which we have anti- 
secretory data, the corresponding healing rate for duodenal ulcer was also derived. This involved an additional review of published clinical trials. Of these, 141 were considered suitable for inclusion being double blinded, randomised and endoscopically controlled. There was a total of 11578 patient evaluations including 9469 patient evaluations in 103 trials of $\mathrm{H}_{2}$ receptor antagonists. Most data were obtained from clinical trials lasting four weeks.

Different trials of the same dosage schedule were combined to obtain composite healing rates. From each trial, the total number of patients assigned to any specific treatment or to placebo was calculated. In addition, the total number of patients with ulcer healing at two, four, six and eight weeks was calculated as an overall percentage healing rate for that treatment. This effectively provides a weighted mean and is more accurate than simply obtaining the crude mean percentage healing rate from all studies, since trials with low patient numbers might have resulted in spuriously high or low healing rates.

For each treatment studied, we have different measurements of pharmacological effect in terms of suppression of acid secretion, and a corresponding measurement of therapeutic effect in terms of ulcer healing. In order to examine for any relationship between the two, we first sought to establish whether a correlation existed. Standard linear regression techniques, ${ }^{32}$ with the antisecretory effect as the independent variable, were used to further investigate the nature of the relationship. In order to establish the relative importance of suppression of acidity by day and night to overall healing rates, stepwise linear regression analysis ${ }^{33}$ was carried out to examine these two factors independently.

\section{Results}

Table 1 shows the ulcer healing rates at four weeks together with data on suppression of 24 hour, nocturnal and daytime acidity for individual dose regimens of the antisecretory drugs studied. These have been ranked according to healing rates. The greatest degree of suppression of acidity occurs with omeprazole followed by nocturnal doses of the $\mathrm{H}_{2}$ receptor antagonists cimetidine $800 \mathrm{mg}$, famotidine $40 \mathrm{mg}$, and ranitidine $300 \mathrm{mg}$.

Included in Table 1 are 11 dose regimens of four different $\mathrm{H}_{2}$ receptor antagonists. Only cimetidine and ranitidine are currently in general use, oxmetidine having been withdrawn from further investigation because of hepatotoxicity, and famotidine currently available only in a few countries. Taking the data for the $\mathrm{H}_{2}$ receptor antagonist regimens alone, there was a significant correlation between suppression of 24 hour acidity and ulcer healing rates
Table 1 Four week healing rates and percentage suppression of 24 hour, nocturnal and daytime acidity produced by various dose regimens of antisecretory drugs, ordered by healing rate.

\begin{tabular}{|c|c|c|c|c|}
\hline $\begin{array}{l}\text { Drug and } \\
\text { dose }\end{array}$ & $\begin{array}{l}\text { Healing } \\
\text { rate at } \\
4 \text { weeks }\end{array}$ & $\begin{array}{l}\text { Suppression } \\
\text { of } 24 \text { hour } \\
\text { acidity }(\%)\end{array}$ & $\begin{array}{l}\text { Suppression } \\
\text { of nocturnal } \\
\text { acidity }(\%)\end{array}$ & $\begin{array}{l}\text { Suppression } \\
\text { of daytime } \\
\text { acidity }(\%)\end{array}$ \\
\hline $\begin{array}{l}\text { Omeprazole } \\
60 \mathrm{mg} \text { mane }\end{array}$ & $100 \cdot 0$ & 96 & 99 & 94 \\
\hline $\begin{array}{l}\text { Omeprazolc } \\
40 \mathrm{mg} \text { manc }\end{array}$ & 98.4 & 98 & 99 & 97 \\
\hline $\begin{array}{l}\text { Omeprazole } \\
20 \mathrm{mg} \text { mane }\end{array}$ & $95 \cdot 5$ & 90 & 88 & 92 \\
\hline $\begin{array}{l}\text { Omeprazole } \\
30 \mathrm{mg} \text { manc }\end{array}$ & $92 \cdot 8$ & 96 & 92 & 99 \\
\hline $\begin{array}{l}\text { Ranitidinc } \\
3(0) \mathrm{mg} \text { nocte }\end{array}$ & $84 \cdot 1$ & 68 & 90 & 50 \\
\hline $\begin{array}{l}\text { Famotidine } \\
40 \mathrm{mg} \text { nocte }\end{array}$ & $82 \cdot 4$ & 64 & 95 & 39 \\
\hline $\begin{array}{l}\text { Cimetidine } \\
8(0) \text { mg nocte }\end{array}$ & $80 \cdot 2$ & 48 & 79 & 23 \\
\hline $\begin{array}{l}\text { Cimetidine } \\
600 \mathrm{mg} \text { bd }\end{array}$ & $80 \cdot 0$ & 67 & 71 & 64 \\
\hline $\begin{array}{l}\text { Ranitidine } \\
150 \mathrm{mg} \text { bd }\end{array}$ & $79 \cdot()$ & 68 & 70 & 66 \\
\hline $\begin{array}{l}\text { Oxmetidine } \\
400 \mathrm{mg} \text { bd }\end{array}$ & $76 \cdot 0$ & 38 & 58 & 22 \\
\hline $\begin{array}{l}\text { Ranitidine } \\
150 \mathrm{mg} \text { nocte }\end{array}$ & $75 \cdot 5$ & 45 & 76 & 20 \\
\hline $\begin{array}{l}\text { Cimetidine } \\
300 \mathrm{mg} \text { qid }\end{array}$ & $74 \cdot 2$ & 65 & 68 & 63 \\
\hline $\begin{array}{l}\text { Cimetidine } \\
200 \mathrm{mg} \text { tid } \\
+400 \mathrm{mg} \text { nocte }\end{array}$ & $\begin{array}{l}73 \cdot 7 \\
e^{2}\end{array}$ & 56 & 72 & 43 \\
\hline $\begin{array}{l}\text { Cimetidine } \\
400 \mathrm{mg} \text { bd }\end{array}$ & $72 \cdot 1$ & 37 & 54 & 23 \\
\hline $\begin{array}{l}\text { Enprostil } \\
35 \mu \mathrm{g} \text { bd }\end{array}$ & $69 \cdot 8$ & 34 & 60 & 13 \\
\hline $\begin{array}{l}\text { Antacid } \\
1000 \mathrm{mmol}\end{array}$ & $67 \cdot 2$ & 50 & 31 & 65 \\
\hline $\begin{array}{l}\text { Cimetidine } \\
200 \mathrm{mg} \text { qid }\end{array}$ & $60 \cdot 6$ & 40) & 24 & 53 \\
\hline
\end{tabular}

at four weeks $(r=0 \cdot 68 ; n=11 ; p=0 \cdot 02)$. There was a highly significant correlation between suppression of nocturnal acidity and ulcer healing at four weeks $(\mathrm{r}=0.926 ; \mathrm{n}=11 ; \mathrm{p}=0.0001)$. By comparison, there was a poor correlation between ulcer healing and suppression of daytime acidity $(r=0.02 ; n=11$; $\mathrm{p}=0.96)$ or nocturnal acid output $(\mathrm{r}=0 \cdot 17 ; \mathrm{n}=7$; $\mathrm{p}=0.71)$.

In order to test the validity of our formula for the calculation of daytime acidity, we applied it to three papers for which suppression of acid for the daytime period was clearly reported..$^{192326}$ For the 11 drug doses studied in these papers covering a wide range of acid suppression, not all were used in our metaanalysis, the deviation of our formula from the actual suppression varied from $-2 \cdot 2 \%$ to $+0.8 \%$ (mean deviation $2 \cdot 3 \%$ ).

Figure 1 shows the relationship between suppres- 


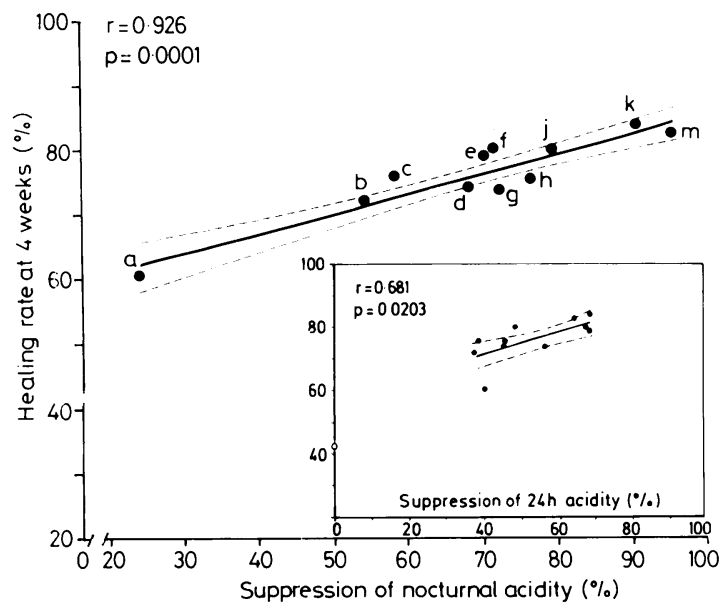

Fig. 1 Regression line and $95 \%$ confidence limits between suppression of acidity ( $\%)$ and healing rate $(\%)$ at four weeks for 11 dose regimens of $\mathrm{H}_{2}$ receptor antagonists, (Fig. I) and all drugs (Fig. 2). Key to symbols: Closed circles (O)

represent data points for $\mathrm{H}_{2}$ antagonists: a = cimetidine 200 mg qid; $b=$ cimetidine $400 \mathrm{mg}$ bd; $c=$ oxmetidine $400 \mathrm{mg} \mathrm{bd}$; $d=$ cimetidine $300 \mathrm{mg}$ qid; $e=$ ranitidine $150 \mathrm{mg}$ bd; $f=$ cimetidine $600 \mathrm{mg} \mathrm{bd} ; \mathrm{g}=$ cimetidine $1 \mathrm{~g} /$ day $(=200 \mathrm{mg}$ tid $+400 \mathrm{mg}$ nocte) $; \mathrm{h}=$ ranitidine $150 \mathrm{mg}$ nocte $; j=$ cimetidine $800 \mathrm{mg}$ nocte $;=$ ranitidine $300 \mathrm{mg}$ nocte; $m=$ famotidine 40 mg nocte. Open squares $(\square): I=$ omeprazole 20 mg mane; $2=$ omeprazole $30 \mathrm{mg}$ mane; $3=$ omeprazole $40 \mathrm{mg}$ mane; $4=$ omeprazole $60 \mathrm{mg}$ mane. Open triangle $(\triangle)=$ enprostil $35 \mathrm{ug}$ bd; Open diamond $(\diamond)=$ antacid $1000 \mathrm{mmol} /$ day; Open circle $(\bigcirc)=$ placebo.

sion of nocturnal acidity and duodenal ulcer healing rates at four weeks for the 11 dose regimens of $\mathrm{H}_{2}$ receptor antagonists listed above, and excluding placebo. The slope of this line is $0.310(95 \%$ confidence limits $0 \cdot 215,0 \cdot 406$ ), with an intercept on the Y-axis of $54 \cdot 8$ (95\% confidence limits $48 \cdot 0,61 \cdot 6)$. Point 'a' on Figure 1, which corresponds to cimetidine $200 \mathrm{mg}$ qid, appears to be separate from the majority of the data points for the other dosage regimens. If this point were to be excluded from the analysis, however, there would still be a highly significant correlation $(r=0.80 ; n=10 ; p=0.0054)$, and neither the slope nor the intercept of the line would change significantly. The insert in Figure 1 shows the relationship between suppression of 24

Table 2 Results of stepwise linear regression analysis for suppression of acidity by night and day for the 11 dose regimens of $\mathrm{H}_{2}$ receptor antagonists

\begin{tabular}{llllll}
\hline Stepn & Variable & Beta & $(S E)$ & $p$ & Increase in $R^{2}$ \\
\hline 1 & Acidity, night & $0 \cdot 309$ & $(0 \cdot 042)$ & $0 \cdot(0004$ & $86 \cdot 1 \%$ \\
2 & Acidity, day & $(0 \cdot(20)$ & $(0 \cdot(045)$ & $0 \cdot 67$ & $0 \cdot 3 \%$ \\
\hline
\end{tabular}

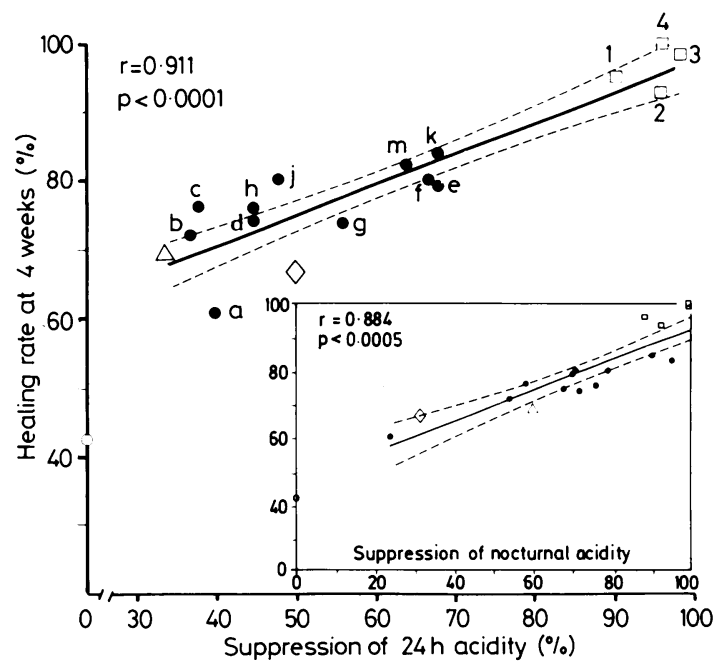

Fig. 2 (Seelegend for Fig. 1).

hour intragastric acidity and four week healing rates for the same 11 dose regimens of $\mathrm{H}_{2}$ receptor antagonists.

In view of the better correlation between healing and suppression of nocturnal rather than 24 hour acidity for the $\mathrm{H}_{2}$ receptor antagonists, stepwise linear regression analysis was performed to examine the relative importance of suppression of nocturnal and daytime acidity to overall healing rates. These results are presented in Table 2 . There is a significant $(p=0.0004)$ association between suppression of acidity at night and ulcer healing. This is responsible for $86.1 \%$ of observed variation in healing rates $\left(R^{2}=0.861\right)$. When suppression of acidity by day is stepped into the analysis, there is no significant association with healing $(\mathrm{p}=0 \cdot 67)$, and suppression of daytime acidity only contributes a further $0.3 \%$ to the observed variation in healing rates.

In Figure 2, the relationship between suppression of 24 hour acidity and healing rates at four weeks is shown for all drugs studied. In addition to the 11 dose regimens of the $\mathrm{H}_{2}$ receptor antagonists, this also includes enprostil, a synthetic prostaglandin $E_{2}$ analogue, in the dose of $35 \mu \mathrm{g} \mathrm{bd}$, antacid, 1000 mmol buffering capacity per day, and four doses of omeprazole $(20,30,40$, and $60 \mathrm{mg}$ per day). Between

Table 3 Results of stepwise linear regression analysis for suppression of acidity by night and day for all antisecretory drugs

\begin{tabular}{llllll}
\hline Step $n$ & Variable & Beta & $(S E)$ & $p$ & Increase in $R^{2}$ \\
\hline 1 & Acidity, night & 0.449 & $(0 \cdot 061)$ & $<0 \cdot(0001$ & $78 \cdot 2 \%$ \\
2 & Acidity, day & 0.1513 & $(0.033)$ & $0 \cdot(006$ & $12.6 \%$ \\
\hline
\end{tabular}




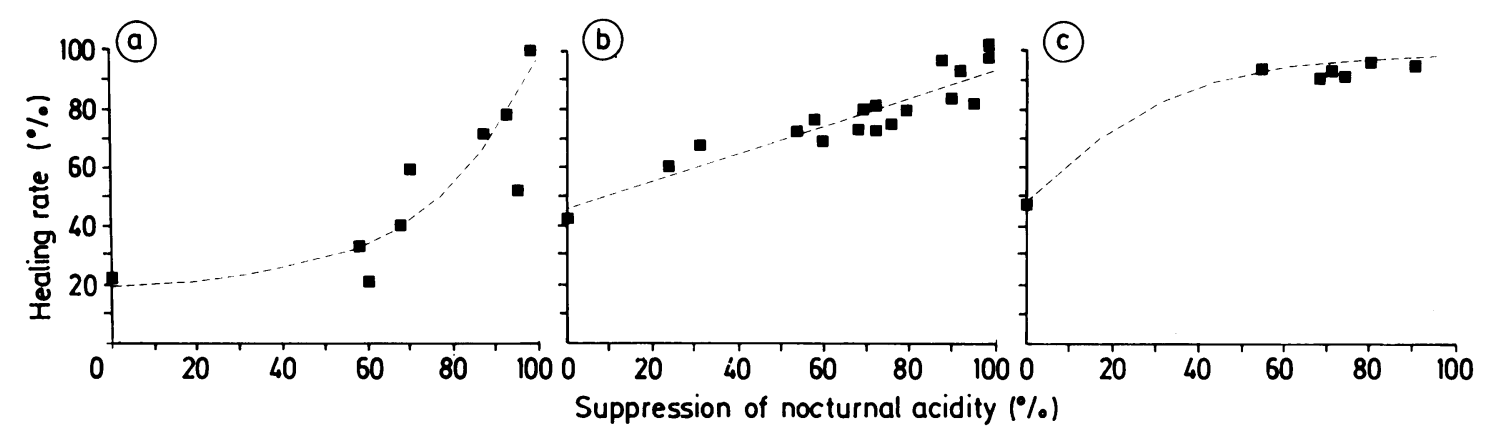

Fig. 3 Relationship between suppression of nocturnal acidity (\%) and healing rates at different timepoints. Panel (a) represents relationship at two weeks; panel (b) at four weeks; panel (c) at eight weeks. (Because of the lack of data points below the level of $60 \%$ suppression, the fit of the lines in panels $(a)$ and $(c)$ are hypothetical.)

suppression of 24 hour acidity and healing rates at four weeks there is a highly significant correlation $(\mathrm{r}=0.911 ; \mathrm{n}=18 ; \mathrm{p}<0.0001)$. The slope of the line is $0.456(95 \%$ confidence limits $0.352,0.560)$, with an intercept on the $\mathrm{Y}$-axis of $52 \cdot 2$ (95\% confidence limits $45 \cdot 4,59 \cdot 0)$. The insert in Figure 2 shows the relationship between suppression of nocturnal acidity and four week healing rates for all drugs studied. Although there is still a highly significant correlation $(\mathrm{r}=0.88 ; \mathrm{n}=18 ; \mathrm{p}<0.0005)$, this is not as strong as that seen with suppression of total 24 hour acidity, the converse of the situation observed above for the $\mathrm{H}_{2}$ receptor antagonists alone.

When stepwise regression analysis techniques were applied to the data for all drugs (Table 3 ), there was a significantly increased overall correlation by including suppression of daytime acidity in the analysis.

In Table 4, the duodenal ulcer healing rates at two, four, six and eight weeks are shown for all regimens studied. The suppression of nocturnal acidity is also given for each regimen. Ulcer healing rates after eight weeks' treatment with large night time doses of $\mathrm{H}_{2}$ receptor antagonists are comparable to those seen with omeprazole at four weeks. Figure 3 shows the relationship between suppression of nocturnal acidity and duodenal ulcer healing rates after two, four, and eight weeks' treatment all classes of antisecretory drugs. It can be appreciated that the nature of the relationship differs at each of these timepoints, emphasising the important influence that duration of treatment has on any relationship between acid suppression and duodenal ulcer healing.

\section{Discussion}

This paper shows for the first time that there is a clear relationship between acid supression and the rate of duodenal ulcer healing. The methods which we have used to explore this relationship provide us with important information about those antisecretory drugs which are currently available for ulcer therapy and the optimal dosing of those doses so far investigated. The meta-analysis technique cannot be used, however, to determine precisely the optimal degree or duration of acid supression. Nevertheless it is clear that a similar analysis of the raw data from a large number of clinical pharmacological studies of acid suppression would probably provide information on a threshold for ulcer healing. A threshold secretion rate of $12 \mathrm{mmol} / \mathrm{h}$ for $\mathrm{MAO}$ to $15 \mathrm{mmol} / \mathrm{h}$ for PAO has been proposed by Baron ${ }^{34}$ from studies of stimulated acid secretion and this is widely used as a target in the treatment of patients with Zollinger-Ellison syndrome.

The validity of our methods of calculation of suppression of daytime acidity clearly was confirmed from applying this to those papers which measured daytime acidity ${ }^{1923} 26$ The results show that we are within less than $2.5 \%$ of the observed.

Analysis of data for the $\mathrm{H}_{2}$ receptor antagonists alone demonstrates a highly significant relationship between four week healing rates for duodenal ulcer and reduction of nocturnal acidity. Furthermore, stepwise linear regression confirms that suppression of nocturnal acidity, with this class of drugs, is primarily responsible for the significant correlation between suppression of 24 hour acidity and four week healing rates. The importance of suppressing nocturnal acidity to achieve maximal healing rates for duodenal ulcer with $\mathrm{H}_{2}$ receptor antagonists is shown in Table 1. With the exception of omeprazole, maximal healing rates of duodenal ulcer after four weeks treatment are achieved with nocturnal doses of $\mathrm{H}_{2}$ receptor antagonists.

The relationship between suppression of 24 hour and nocturnal acidity and ulcer healing at four weeks is linear in the range of suppression produced by $\mathrm{H}_{2}$ receptor antagonists (60 to $95 \%$ ). The extrapolation 
Table 4 Healing rates for duodenal ulcer after two, four, six, and eight weeks of treatment and percentage reduction in nocturnal intragastric acidity produced by various dose regimens of antisecretory drugs

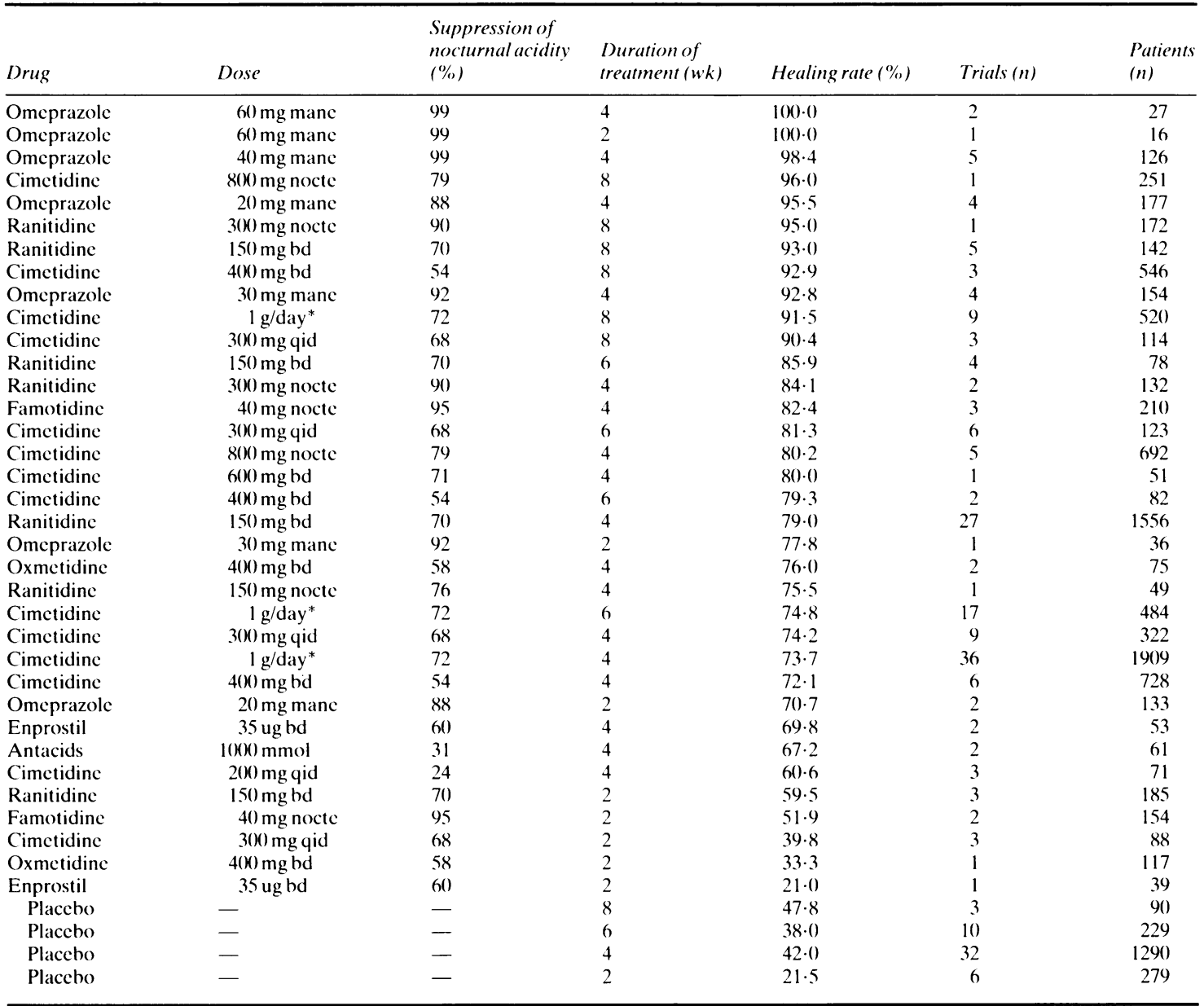

*Cimetidine $1 \mathrm{~g} /$ day $=$ cimetidine $200 \mathrm{mg}$ tid $+400 \mathrm{mg}$ nocte.

of this relationship to either extreme of acid suppression - namely, $0 \%$ or $100 \%$, is unlikely to hold, because the predicted placebo healing rate $(y-$ intercept) of $55 \%$ is above that seen in clinical trials at $42 \%$ (Table 4). The regression line does not predict $100 \%$ ulcer healing at four weeks even with total suppression of acidity which is virtually achieved by omeprazole. The true relationship may therefore be a flat sigmoid curve, although with the paucity of data at low extremes of acid suppression, this relationship is difficult to prove and a flat sigmoid curve is virtually unknown in biology.

When the data for antacids, a prostaglandin, and omeprazole are included in the analysis with $\mathrm{H}_{2}$ receptor antagonists, the ulcer healing at four weeks is better correlated with suppression of 24 hour than with nocturnal acidity. Compared with the data for $\mathrm{H}_{2}$ receptor antagonists alone, where suppression of daytime acidity contributes a negligible amount to suppression of 24 hour acidity (Table 2), the contribution of suppression of daytime acidity to suppression of 24 hour acidity by all classes of drugs when analysed together becomes significant (Table 3 ). This suggests that for some classes of drugs, suppression of daytime acidity might be an additional advantage.

Although doubling the dose of cimetidine from 200 $\mathrm{mg}$ gid to $400 \mathrm{mg}$ qid was not associated with a significantly greater degree of daytime suppression," larger doses of $\mathrm{H}_{2}$ receptor antagonists given during the daytime have not been investigated in clinical trials although cimetidine $600 \mathrm{mg}$ qid (Table 1) gives healing rates at four weeks which is similar to 
cimetidine $800 \mathrm{mg}$ nocte $(30 \%$ smaller total daily dose).

The relative contribution of daytime versus night time suppression of acidity for omeprazole is more difficult to evaluate as this drug has a prolonged duration of action over the 24 hour period after once daily administration, whether taken in the morning or in the evening. ${ }^{3}$

Although potent suppression of either 24 hour or nocturnal acidity leads to healing of duodenal ulcer, the data in Table 4 and Figure 3, emphasise the arbitrary nature of the time points chosen in clinical trials and the importance of duration of treatment to ulcer healing. For example, omeprazole $60 \mathrm{mg}$ achieves $100 \%$ healing of duodenal ulcer after four weeks' treatment, an effect approached by nocturnal doses of $\mathrm{H}_{2}$ receptor antagonists after eight weeks when cimetidine $800 \mathrm{mg}$ nocte and ranitidine $300 \mathrm{mg}$ nocte show healing rates of $96 \%$ and $95 \%$ respectively.

It is not apparent in clinical practice whether rapid healing with short term potent suppression of acid secretion differs from longer term more moderate suppression. The natural history of duodenal ulcer dose not appear to be altered and the truly refractory ulcer is rare. ${ }^{3}$

This analysis has demonstrated a clear relationship between the pharmacological effect of various doses of antisecretory drugs and therapeutic efficacy in the treatment of duodenal ulcer. The importance of clinical pharmacological studies of 24 hour and nocturnal intragastric acidity in predicting healing rates for duodenal ulcer has been clearly established and confirmed. Such studies are not dependent on the relationship between pharmacokinetics and antisecretory effect, as they use data which relate only to pharmacodynamics. Results of these studies argue for a more rational choice of dose and frequency of administration. A knowledge of the ability of an antisecretory drug to suppress 24 hour, and particularly, nocturnal acidity enables an accurate prediction of efficacy in duodenal ulcer.

We are grateful to Dr David L Sackett and Professor Robin S Roberts of the Department of Clinical Epidemiology and Biostatistics of McMaster University for their advice and assistance with statistical methods, and to Dr Janet Elashoff of CURE, Los Angeles, for her advice on the manuscript.

\section{References}

1 Burland WL, Duncan WAM, Hesselbo T, Mills JG, Sharpe PC. Pharmacological evaluation of cimetidine, a new histamine $\mathrm{H}_{2}$ receptor antagonist, in healthy man. Br J Clin Pharmacol 1975; 2: 481-6.
2 Berstad A, Frislid K, Rydning A. Relationship between ranitidine plasma levels and reduction of postprandial intragastric acidity in healthy man. Scand J Gastroenterol 1982; 17: 109-12.

3 Prichard PJ, Yeomans ND, Mihaly GW, et al. Omeprazole: A study of its inhibition of gastric $\mathrm{pH}$ and oral pharmacokinetics after morning and evening dosage. Gastroenterology 1985; 88: 64-9.

4 Gledhill T, Howard OM, Buck M, Paul A, Hunt RH. Single nocturnal doses of an $\mathrm{H}_{2}$ receptor antagonist for the treatment of duodenal ulcer. Gut 1983; 24: 904-8.

5 Feldman M, Richardson CT. Total 24 hour gastric acid secretion in patients with duodenal ulcer. Comparison with normal subjects and effects of cimetidine and parietal cell vagotomy. Gastroenterology 1986; 90: 540-4.

6 Winkelstein A. One hundred and sixty-nine studies in gastric secretion during the night. Am J Dig Dis 1935; 1: 778-82.

7 Levin E, Kirsner JB, Palmer WL. A comparison of the nocturnal gastric secretion in patients with duodenal ulcer and in normal individuals. Gastroenterology 1948; 10: $952-64$.

8 Dragstedt LR. Peptic ulcer, An abnormality in gastric secretion. Am J Surg 1969; 117: 143-56.

9 Pounder RE, Williams JG, Hunt RH, Vincent SH, Milton-Thompson GJ, Misiewicz JJ. The effects of oral cimetidine on food-stimulated gastric acid secretion and 24-hour intragastric acidity. In: Cimetidine. Proceedings of the Second International Symposium on histamine $\mathrm{H}_{2}$ receptor antagonists. Amsterdam: Excerpta Medica, 1977: 189-206.

10 Dronfield MW, Batchelor AJ, Larkworthy W, Langman MJS. Controlled trial of maintenance cimetidine treatment in healed duodenal ulcer: short and longterm effects. Gut 1979; 20: 526-30.

11 Boyd EJS, Wilson JA, Wormsley KG. Maintenance treatment of duodenal and gastric ulcer with ranitidine. In: Ranitidne. Proceedings of an International Symposium held in the context of the Seventh World Congress of Gastroenterology. Amsterdam: Excerpta Medica, 1982: 102-16.

12 Gough KR, Korman MG, Bardhan KD, et al. Ranitidine and cimetidine in prevention of duodenal ulcer relapse. A double-blind, randomized, multicentre, comparative trial. Lancet 1984; ii: 659-62.

13 Hunt RH. Non-responders to cimetidine, Part 1. In: Cimetidine in the 80s. Edinburgh: Churchill Livingstone, 1981: 34-41.

14 Gledhill T, Buck M, Hunt RH. Effect of no treatment, cimetidine $1 \mathrm{~g} /$ day, cimetidine $2 \mathrm{~g}$ /day and cimetidine combined with atropine, on nocturnal gastric secretion in cimetidine non-responders. Gut 1984; 25: 1211-6.

15 Glass GV. Primary, secondary, and meta-analysis of research. Educ Res 1976; 10: 3-8.

16 Walt RP, Male P-J, Rawlings J, et al. Comparison of the effects of ranitidine, cimetidine and placebo on the 24 hour intragastric acidity and nocturnal acid secretion in patients with duodenal ulcer. Gut 1981; 22: 49-54.

17 Pounder RE, Williams JG, Milton-Thompson GJ, Misiewicz JJ. 24-hour control of intragastric acidity in duodenal ulcer patients. Lancet 1975; ii: 1069-73. 
18 Gotthard R, Berstad A, Bodemar G, Norlander B, Walan A. Effect of cimetidine and oxmetidine on 24-h gastric acid and pepsin in patients. Scand J Gastroenterol 1983; 18: 809-17.

19 de Gara CJ, Burget DW, Silletti C, Hunt RH. Is daytime administration of $\mathrm{H}_{2}$ receptor antagonists necessary for the control of acid and pepsin secretion? [Abstract]. Am J Gastroenterol 1984; 79: 819.

20 Dammann HG, Muller P, Simon B. 24 hour intragastric acidity and single night-time dose of three $\mathrm{H}_{2}$-blockers. Lancet 1983; ii: 1078.

21 Blackwood WS, Northfield TC. Nocturnal gastric acid secretion: Effect of cimetidine and interaction with anticholinergics. In: Cimetidine. Proceedings of the Second International Symposium on Histamine $\mathrm{H}_{2}$ Receptor Antagonists. Amsterdam, Oxford: Excerpta Medica, 1977: 124-30.

22 Mahachai V, Walker K, Jamali F, et al. Comparative effects of two cimetidine regimens on 24 hour intragastric acidity in patients with asymptomatic duodenal ulcer. Clin Ther 1984; 6: 259-81.

23 Peterson WL, Barnett C, Feldman M, Richardson CT. Reduction of twenty-four hour gastric acidity with combination drug therapy in patients with duodenal ulcer. Gastroenterology 1979; 77: 1015-20.

24 Sharma BK, Walt RP, Pounder RE, Gomes MdeFA, Wood EC, Logan LH. Optimal dose of oral omeprazole for maximal 24 hour decrease of intragastric acidity. Gut 1984; 25: 957-64.

25 Walt RP, Gomes MdeFA, Wood EC, Logan LH, Pounder RE. Effect of daily oral omeprazole on 24 hour intragastric acidity. $\mathrm{Br}$ Med J 1983; 287: 12-4.

26 Naesdal J, Bodemar G, Walan A. Effect of omeprazole, a substituted benzimidazole, on 24-h intragastric acidity in patients with peptic ulcer disease. Scand J Gastroenterol 1984; 19: 916-22.

27 Milton-Thompson GJ, Wright B, Vincent D, Hunt RH. Comparisons of 24-hour intragastric acidity in duodenal ulcer patients on high dose antacid or cimetidine [Abstract]. Gastroenterology 1979; 76: 1204.

28 Santana IA, Sharma BK, Orchard K, Pounder RE. Twenty four hour intragastric acidity before and during treatment with enprostil [Abstract]. Gut 1985; 26: A545.

29 Deakin M, Ramage JK, Paul A, Gray S, Billings J, Williams JG. Effect of enprostil on 24 hour intragastric acidity and nocturnal acid and pepsin output [Abstract]. Gut 1985; 26: A545.

30 Mahachai V, Reilly P, Thomson ABR. Comparative effects of pirenzepine and cimetidine, alone and in combination, on 24-hour gastric acidity in duodenal ulcer disease. Clin Ther 1985; 7: 98-111.

31 Pounder RE, Hunt RH, Vincent SH, Milton Thompson GJ, Misiewicz JJ. 24 hour intragastric acidity and nocturnal acid secretion in patients with duodenal ulcer during and administration of cimetidine and atropine. Gut 1977; 18: 85-90.

32 Goldman L, Feinstein AR. Anticoagulants and Myocardial Infarction: the problems of pooling drowning and floating. Ann Intern Med 1979; 90: 92-4.

33 Kleinbaum DG, Kupper LL. Applied regression analysis and other multivariate methods. Boston, Massachusetts: Duxbury Press, 1978.

34 Baron JH. The clinical application of gastric secretion measurements. Clin Gastroenterol 1973; 2: 293-314. 